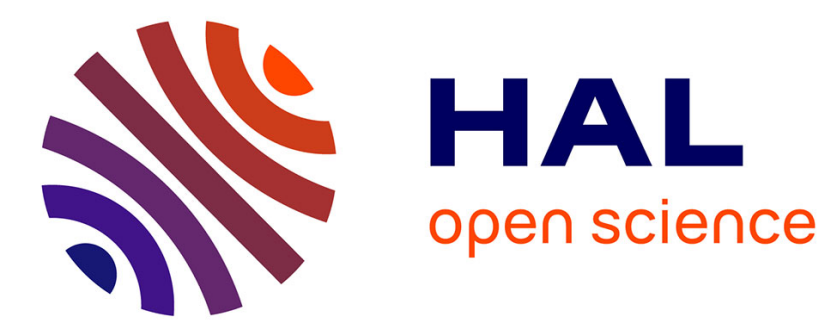

\title{
Radio-tracking of male adult Atlantic salmon, Salmo salar L., during the last phase of spawning migration in a spawning stream (Brittany, France)
}

\author{
Jean-Luc J.-L. Baglinière, Gérard Maisse, A. Nihouarn
}

\section{To cite this version:}

Jean-Luc J.-L. Baglinière, Gérard Maisse, A. Nihouarn. Radio-tracking of male adult Atlantic salmon, Salmo salar L., during the last phase of spawning migration in a spawning stream (Brittany, France). Aquatic Living Resources, 1991, 4, pp.161-167. 10.1051/alr:1991017 . hal-02715496

\author{
HAL Id: hal-02715496 \\ https://hal.inrae.fr/hal-02715496
}

Submitted on 1 Jun 2020

HAL is a multi-disciplinary open access archive for the deposit and dissemination of scientific research documents, whether they are published or not. The documents may come from teaching and research institutions in France or abroad, or from public or private research centers.
L'archive ouverte pluridisciplinaire HAL, est destinée au dépôt et à la diffusion de documents scientifiques de niveau recherche, publiés ou non, émanant des établissements d'enseignement et de recherche français ou étrangers, des laboratoires publics ou privés. 


\title{
Radio-tracking of male adult Atlantic salmon, Salmo salar L., during the last phase of spawning migration in a spawning stream (Brittany, France)
}

\author{
Jcan-Luc Baglinière ${ }^{(1)}$, Gćrard Maisse ${ }^{(1)}$ and Alix Nihouarn ${ }^{(2)}$ \\ (1) I.WRA, Station de Physiologie et disologie des Poissoms, \\ 6ij, rue de Saint-Brieuc, 350 g. Rennes Cieder, France. \\ (2) Délégation Régionale Bretagne-Basse-Normandie du Conséil Supéricur de la Péche, \\ 84, rue de Rennes, 35510 (ésson Sérigné, France.
}

Received January 28, 1991; accepted May 30, 1991.

Abstract

Résumé

Bagliniere J.-L., G. Maisse, A. Nihouarn. Aquat. Lizing Resour., 1991, 4, 161-167.

The final phase of spawning migration of eight adult malc Atlantic salmon, Salmo salar L., was analysed by radio-tracking in relation to sca age and size in a spawning tributary of the River Sélune. Four grilse and four multi sea-winter fish, one of which as a previous spawner, were radio-tagged and released. Their fork length ranged from 602 to $882 \mathrm{~mm}$. The daily movement in the first two days after relcasc and the furthest upstream distance recorded from the trap during the study period were independent of fish length. Maximum amplitude of movement observed over the entire study period was inversely correlated with length. Daily movement decreased in all males during the spawning period and was negatively correlated with the size of fish. Surviving males remaincd in the vicinity of the spawning grounds after spawning. It was concluded that the length of male seemed to influence its behaviour in the last phasc of the spawning migration, enabling a much more successful participation of the larger males in spawning.

Keywords : Atlantic salmon, Salmo salar, stream, migration, reproduction, behaviour, radio-tracking.

Radiopistage du mâle adulte de saumon Atlantique, Salmo salar L., durant la derniëre phase de la migration de reproduction sur un affluent frayère (Bretagne, France).

La phase finale de la migration de reproduction de huit mâles adultes de saumon atlantique (Salmo salar L.) est ćtudiéc par radiopistage en liaison avec la taille et l'âge de mer des poissons sur un affluent frayère de la Sélune. Quatre de ces poissons étaient des grilses, les quatre autres ćtaicnt des poissons de plusieurs hivers de mer dont l'un d'entre cux s'ćtait déjà reproduit une première fois. Leur taille (longucur fourche) s"échelonnait de 602 à $882 \mathrm{~mm}$. Le taux de déplacement journalier durant les deux premiers jours après le relâcher et le point extrême de migration amont enregistré durant la période d'étude sont indépendants de la longucur du poisson. L'amplitude maximale des mouvements observés au cours de cette période était correlé négativement avec la longueur. I.e déplacement journalier diminuait fortement durant la période de reproduction el était correlé négativement à la taille du poisson. Après la fraie, les mảles survivants restaient à proximité des frayères. Il est conclu de cette étude que la taille du saumon adulte mâle semble inlluencer son comportement lors de la dernière phase de sa migration de reproduction, permettant aux grands mâles un taux beaucoup plus élevé de participation à la reproduction.

Mots-clés : Saumon atlantique, Salmo salar L., rivière, migration, reproduction, comportement, radiopistage. 


\section{INTRODUCTION}

When adult salmon reach the river, migration takes place generally in three successive phases: rapid movement upstream for either long or short distances, then a long residence period, followed by a short upstream migration just before spawning (Hawkins and Smith, 1986; Heggberget et al., 1988). Numerous studies have been carried out, notably on the first phase, to determine distances and speed of migration (Power and McCleave, 1980; Baril and Gueneau, 1986; Hawkins and Smith, 1986; Heggberget et al., 1988; Laughton, 1989; Webb, 1989). The reproductive behaviour of Atlantic salmon has been well documented (Jones and King, 1949; Beall and Marty, 1983). However, the third migratory phase corresponding to upstream movement of the fish towards the spawning zones, has hardly been studied, with the exception of work carried out by Heggberget et al. (1988) and Webb and Hawkins (1989).

Thus we began a radio-tagging study describing the final phase of spawning migration of adult salmon in the River Oir, a tributary of the River Sélune in Normandy. Irirst observations showed that the upstream run took place in late autumn just before spawning, most adults are grilse mainly in males ( 65 to $93 \%$ from 1984 to 1990: unpublished data) and that both ovulated and non-ovulated females were caught at the trap. A first part of this radio-tracking study carried out in 1988 has described certain characteristics of the migratory and reproductive behaviour of females and concluded that their ripeness did not influence their behaviour (Baglinière et al., 1990). In the second part presented here, radio-tracking was also used to investigate the final phase of spawning migration of males and particulary their reproductive behaviour and their level of participation in spawning in relation to the size and sca age.

\section{MATERIAL AND METHODS}

The experiment was carried out on the River ()ir, a right bank tributary of the River Sélune, a river in the Armorican Massif (France), between 14 December 1989 and 2 January 1990 (fig. 1). The characteristics of the environment have been described by Bagliniere et al. (1988). The tributary is $19.5 \mathrm{~km}$ long with a drainage area of approximately $85 \mathrm{~km}^{2}$. The spawning zone for salmon is distributed over $12.3 \mathrm{~km}$ of the main course of the river between a point $2.2 \mathrm{~km}$ upstream of the trapping site and Buat water mill dam, which is impassable. The trap is located $2.3 \mathrm{~km}$ from the confluence with the River Sélune. Downstream from the trap, the River Oir is deep and has very few sites suitable for spawning (riffles and fast runs). In the spawning zone, the average width of the river is $3.5 \mathrm{~m}$ and there are seven tributaries including Pont Levesque $15.4 \mathrm{~km}$, average width $2 \mathrm{~m})$ and La Roche Brooks $(3.4 \mathrm{~km}$, average width $1.80 \mathrm{~m}$ ).

In 1989, the upstream migration of adult salmon took place in very late autumn in the River Oir (fig. 2) since only one fish was trapped before this period (30th April). The characteristics of adult salmon released above the trap in the River Oir are given in tahle 1.

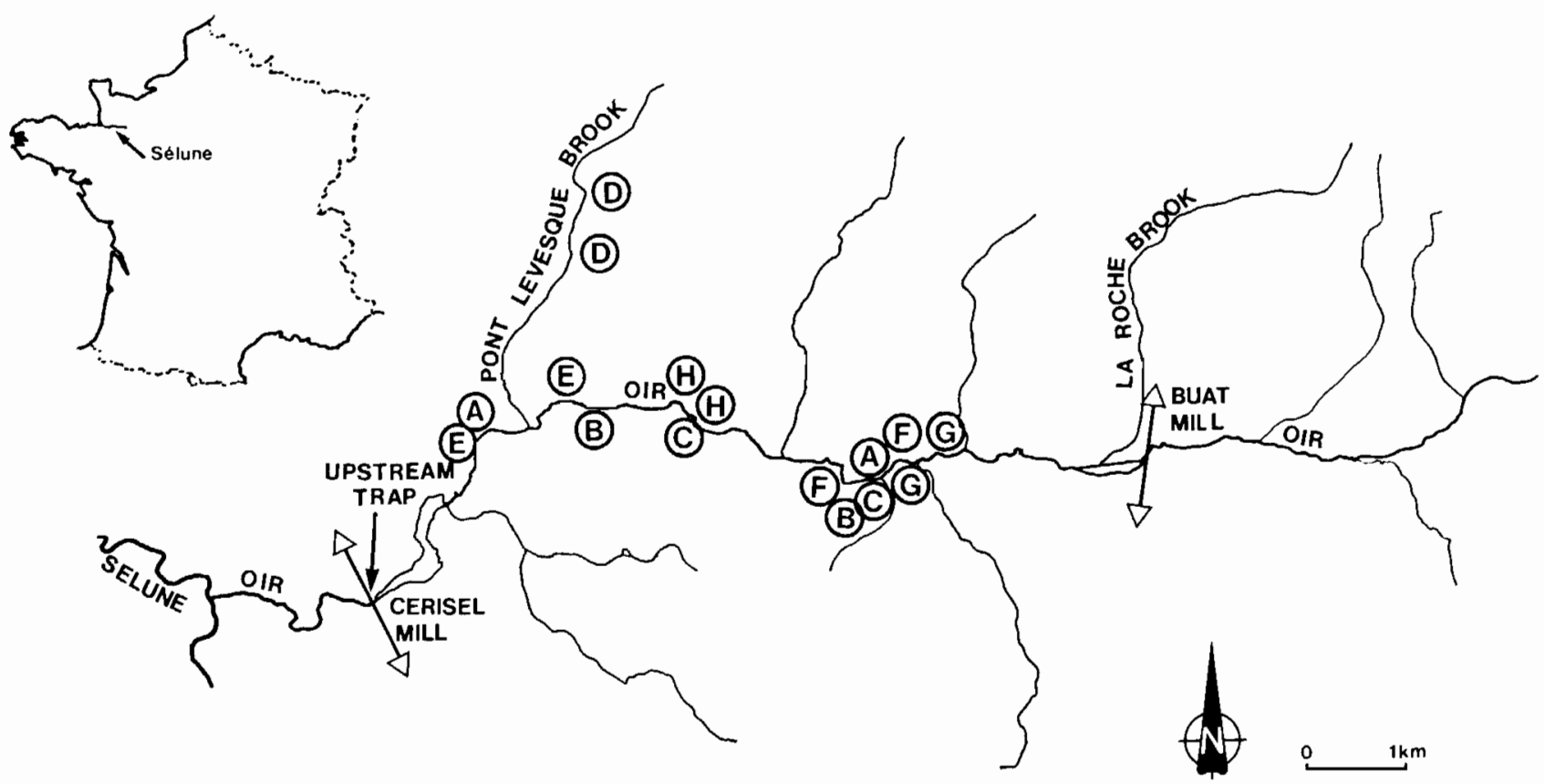

Figure 1. The water course of the River Oir showing limits of the study area during the 1989 spawning season. The letters corresponding to the eight tracked fish mark the furthest positions recorded during the study period. 
Table 1. -. Characteristics of adult salmon released above the trap in the River Oir in 1989.

\begin{tabular}{|c|c|c|c|c|c|c|}
\hline \multirow[b]{2}{*}{ Sed-age } & \multicolumn{2}{|c|}{ Male } & \multicolumn{3}{|c|}{ Female } & \multirow{2}{*}{$\begin{array}{l}\text { Total } \\
\text { Fork length } \\
\text { (mm) }\end{array}$} \\
\hline & Number & $\begin{array}{l}\text { Fork length } \\
(\mathrm{mm})\end{array}$ & Number & $\begin{array}{l}\text { Fork length } \\
(\mathrm{mm})\end{array}$ & Number & \\
\hline Grilse & 124 & $\begin{array}{c}651 \\
(38.0)\end{array}$ & 52 & $\begin{array}{c}640 \\
(30.1)\end{array}$ & 176 & $\begin{array}{c}648 \\
(37.2)\end{array}$ \\
\hline Multi-sea-winter fish & 11 & $\begin{array}{c}777 \\
(38.6)\end{array}$ & 11 & $\begin{array}{c}785 \\
(63.9)\end{array}$ & 22 & $\begin{array}{c}779 \\
(52.4)\end{array}$ \\
\hline Total & 1.35 & $\begin{array}{c}661 \\
(51.4)\end{array}$ & 63 & $\begin{array}{c}666 \\
(66.8)\end{array}$ & 198 & $\begin{array}{c}663 \\
(56.7)\end{array}$ \\
\hline
\end{tabular}

( ) Standard deviation.

Eight adult malc salmon (5.9\% of the 135 fish males released above the trap; $3.3 \%$ of the 124 grilse males and $36.4 \%$ of the 11 multi sea-winter males) were trapped at Cerisel water mill on 13 and 14 December 1989 , at the beginning of the period of maximum upstream migration in the River Oir (fig. 2). Four of the fish were grilse, the others were multi sea-winter fish, one of which was a previous spawner. Their size ranged from 602 to $882 \mathrm{~mm}$ fork length (table 2). The handling protocol used in this study has been presented by Baglinière et al. (1990). After anesthesia, a lubricated radio transmitter was placed in the fish's stomach and a $29 \mathrm{~cm}$ antenna was brought out through the lower part of the gill. This all took less than 1 min. The salmon was then placed in a tank, immersed in the head bay above the trap, from which it could leave frecly. All fish were handled, tagged released and on the evening of 14 December, the radio-transmitter weighed $16 \mathrm{~g}$ and was $45 \mathrm{~mm}$ long and $16 \mathrm{~mm}$ wide. Its working life was only between 110 and 150 days as they were used for the females the previous year. Each tag operated on a different radio frequency between 48 and $49 \mathrm{MHz}$. The transmitter range was between 0.5 and $1 \mathrm{~km}$ depending on the terrain.

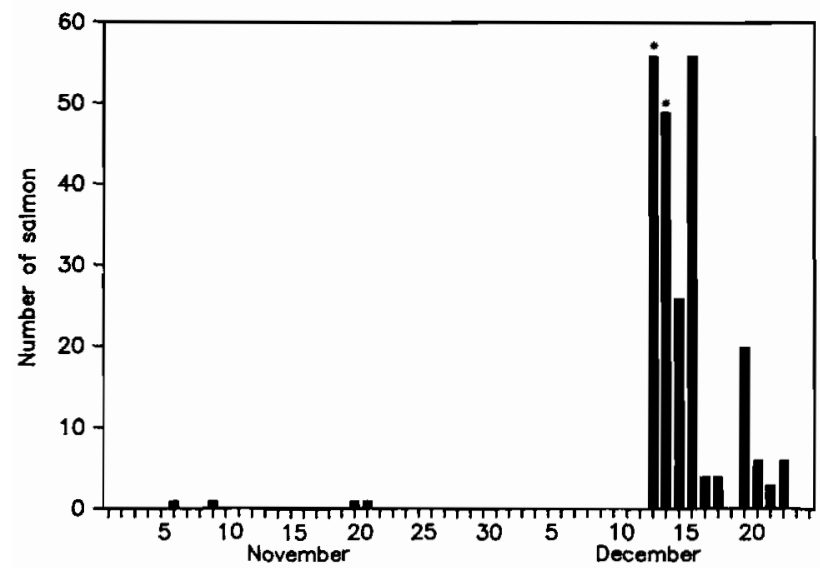

Figure 2. - The daily number of Atlantic salmon adults caught by trapping at Cerisel Mill in the River Oir in 1989. Asterisks mark date of capture of adult male salmon used in this study.
All fish studied were subsequently located daily by radio-tracking, using two readings for cross-checking purposes, enabling positions to be determined within $10 \mathrm{~m}$ on a 1: 2000 scale map. Very low water level often allowed visual observations from the bank, enabling a more accurate location of tagged salmon and also the period of spawning activity of females (digging redds) could be recorded very precisely.

Males are identificd by the letters $A$ to $H$ and their daily position was measured in kilometers from the trap. The maximum amplitude of movement was expressed by the distance (in $\mathrm{km}$ ) between the furthest positions recorded during the study period.

All the males were recorded dead after spawning.

Water level and temperature were recorded continuously during the study period at the trap; barometric pressure and cloud cover were noted daily (fig. 3).

The behaviour of fish has been analysed with a Factor Analysis (Principal Component Analysis) in taking into account the variables presented in the table 3 except the location of spawning.

Table 2. - Characteristics of the male Atlantic salmon, Salmo salar L., adults studied by radio-lracking in the River Oir.

\begin{tabular}{|c|c|c|c|c|}
\hline \multicolumn{2}{|c|}{ Male } & \multirow[b]{2}{*}{$\begin{array}{l}\text { Date of } \\
\text { capturc }\end{array}$} & \multicolumn{2}{|c|}{ Age } \\
\hline Name & $\begin{array}{l}\text { Fork } \\
\text { length } \\
(\mathrm{mm})\end{array}$ & & River & Sea \\
\hline A & 602 & $14-12$ & 1 & $1+$ \\
\hline B & 632 & $13-12$ & 1 & $1+$ \\
\hline $\mathrm{C}$ & 645 & $13-12$ & 1 & $1+$ \\
\hline D & 667 & $13-12$ & 1 & $1+$ \\
\hline E. & 754 & $13-12$ & 1 & $\geqq 2^{*}$ \\
\hline$F$ & 755 & $14-12$ & 2 & $\geqq 2 *$ \\
\hline G & 758 & $14-12$ & 1 & $\geqq 2^{*}$ \\
\hline$H$ & 882 & $14-12$ & 1 & $2 \mathrm{SM}^{* *} 1$ \\
\hline
\end{tabular}

* Scale edge eroded.

** $\mathrm{SM}=$ spawning mark. 

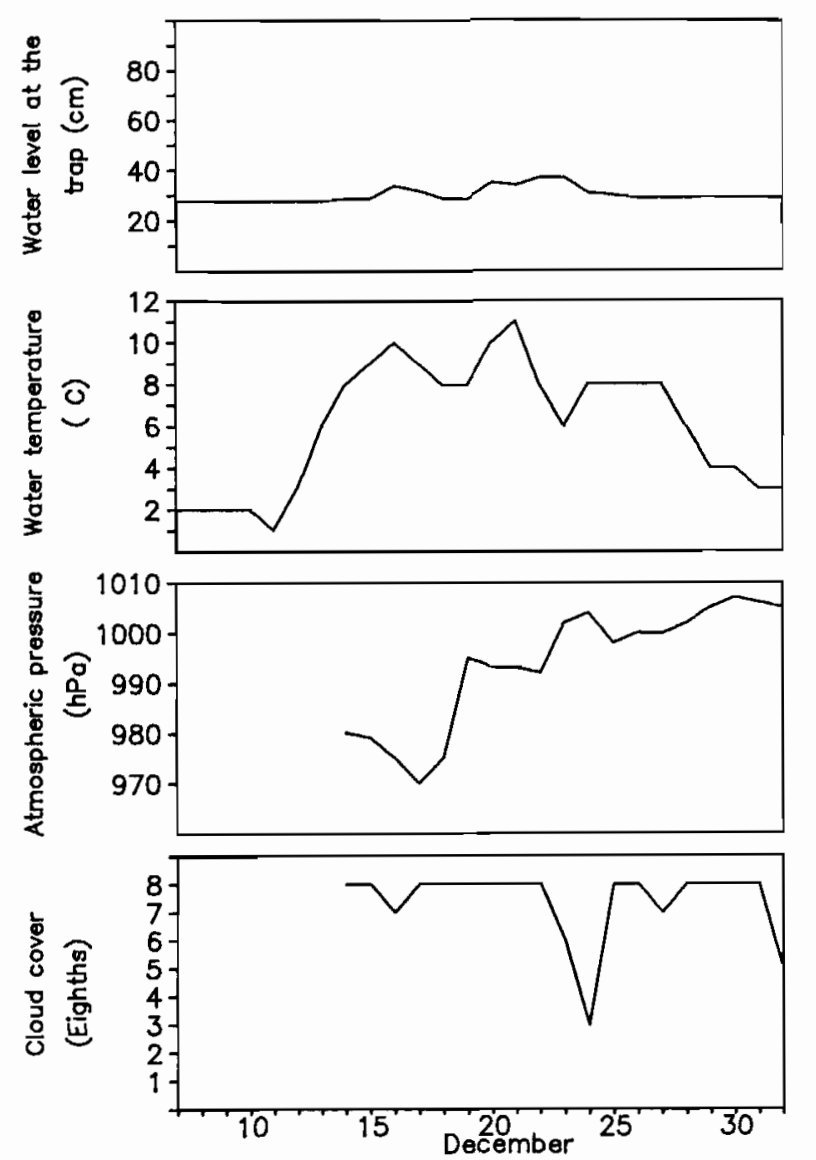

Figure 3, - Record of daily water level below the trap, water temperature, atmospheric pressure, cloud cover at the trap during the period 14 I Jecember 1989-2 January 1990 on the River Oir.

\section{RESULTS}

All the radio-tagged males left the head bay above the trap on the evening of the day of release (14 December) or the next night since all except $F$ (no localization) were recorded outside the head bay (length of $2.2 \mathrm{~km}$ ) at distances ranging from 2.64 to $8.90 \mathrm{~km}$ the trap at 9 a.m. the following morning (fig. 4).

The distance covered in the first two days following departure ranged from 4.37 to $9.61 \mathrm{~km}$, corresponding to a minimum speed of 2.19 to $4.8 \mathrm{~km} / \mathrm{dat}$. This distance was between 93 and $100 \%$ of the total distance they migratcd upstream ( fig. 4 and table 3 ) and was correlated positively with the furthest upstream point of migration $(r=0.99, p<0.01)$ and the daily movement during pre-spawning period $(r=0.76$, $p<0.05$ ) (fig. 5). The second day after release, we recorded a small downstream movement by two fish (B, G) ( fig. 4). During this period, the water temperature increased from 8 to $10^{\circ} \mathrm{C}$ while the water level rose very slightly (fig. 3 ). The daily movement during the first two days was not related to size of the fish (fig. 5).
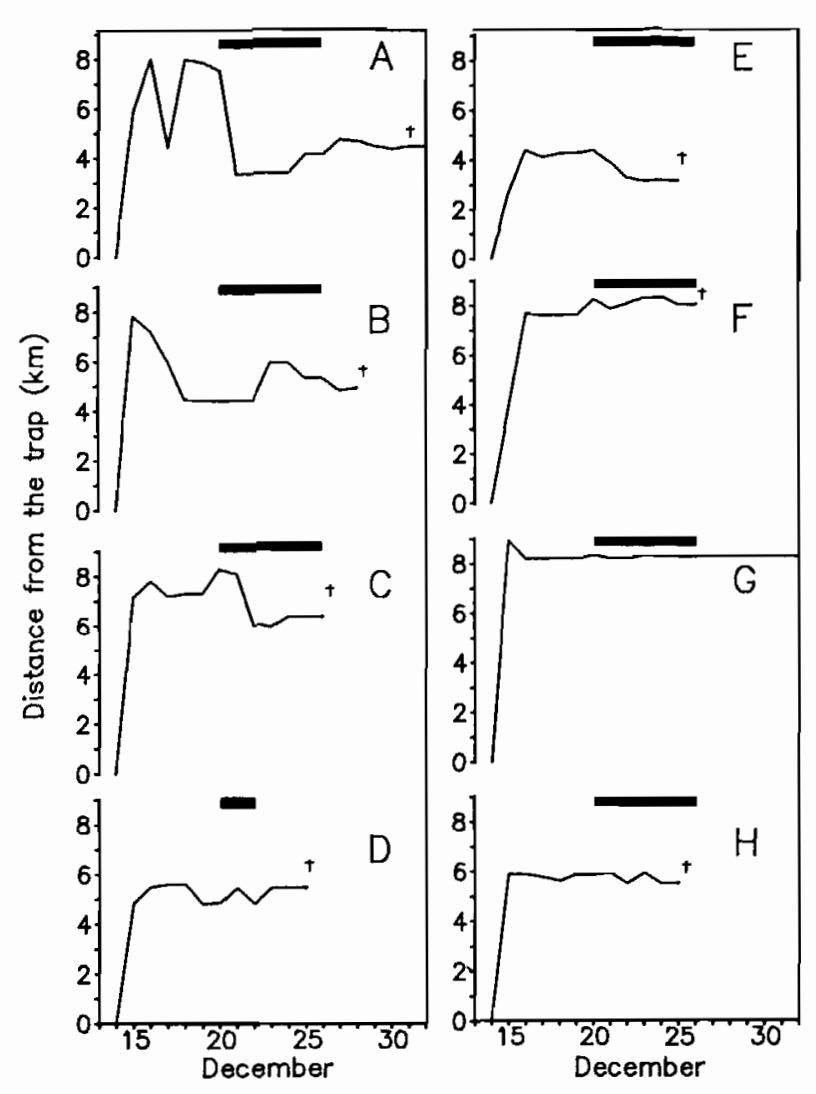

Figure 4. - Daily movements of eight male salmon (A-H) studied before, during and after spawning ( spawning period, $t$ death). The left side of the figure depicts movements of grisle males, the right side movements of multi sea-winter fish male. Fish D spawned in the Pont Levesque Brook while all others spawned in the River Oir.

The furthest upstream point of migration and the day on which it was reached varied and did not appear to depend on the size and sea-age of the fish (fig. 5). Seven fish, of which three were grilse, migrated in the lower or middle part of the river, up to a distance of between 4.4 and $8.9 \mathrm{~km}$ from the trap, 1-7 days after release (fig. 4, table 3). Morcover, the furthest upstream positions of five fish were very close together. Only one male grilse (D) ran into a tributary (Pont Levesque Brook) where it reached a maximum distance of $5.57 \mathrm{~km}$ from the trap (approximatively $2 \mathrm{~km}$ from the confluence with the river) 3 days after release ( $f$ ig. 1 and 4 ).

Over the period of study, no clear relationship was found between the daily movement of fish and the recorded climatic factors. On the other hand, daily movement during pre-spawning period appeared more to depend on the size of malc. Three of the grilsc $(\Lambda, B, C)$ moved upstream and downstream up to several kilometers beyond their position recorded after the first two days, whereas the other grisle (the largest), which migrated in Pont Levesque Brook, and the four larger salmon went little distance beyond that position (fig. 4). There was a negative correlation 
Table 3. - Characteristics of movement of the radio-tagged adult male salmon over the last phase of spawning migration in River Oir (date of release from trap: 14 December 1989).

\begin{tabular}{|c|c|c|c|c|c|c|c|c|}
\hline \multirow{3}{*}{ Identity } & Fish & \multirow{3}{*}{$\begin{array}{c}\text { Movement } \\
\text { during the } \\
\text { two first } \\
\text { days } \\
(\mathrm{km}) \\
M 2 D{ }^{\left({ }^{1}\right)}\end{array}$} & \multicolumn{2}{|c|}{$\begin{array}{c}\text { Daily movement } \\
(\mathrm{km} \text {. day }-1) \text { during }\end{array}$} & \multicolumn{2}{|c|}{$\begin{array}{c}\text { Furthest upstream } \\
\text { position }\end{array}$} & \multirow{3}{*}{$\begin{array}{l}\text { Maximum } \\
\text { amplitude } \\
\text { of } \\
\text { movement } \\
M A M\left({ }^{1}\right)\end{array}$} & \multirow{3}{*}{$\begin{array}{c}\text { Location } \\
\text { of } \\
\text { spawning }\end{array}$} \\
\hline & \multirow{2}{*}{$\begin{array}{l}\text { Fork } \\
\text { length } \\
(\mathrm{mm}) \\
F L\left({ }^{1}\right)\end{array}$} & & $\begin{array}{l}\text { Pre- } \\
\text { spawning } \\
\text { period }\end{array}$ & $\begin{array}{l}\text { Spawning } \\
\text { period }\end{array}$ & $\begin{array}{l}\text { Distance } \\
\text { from } \\
\text { the trap } \\
(\mathrm{km})\end{array}$ & $\begin{array}{c}\text { Number of } \\
\text { days } \\
\text { to reach } \\
\text { this } \\
\text { position }\end{array}$ & & \\
\hline & & & $D M P\left({ }^{1}\right)$ & $\operatorname{DMS}\left({ }^{1}\right)$ & $D F M\left({ }^{1}\right)$ & $N F M\left({ }^{1}\right)$ & & \\
\hline B & 632 & 7.25 & 1.87 & 0.35 & 7.82 & 1 & 3.38 & R. Oir \\
\hline C & 645 & 7.90 & 1.57 & 0.62 & 8.28 & 6 & 2.34 & $\begin{array}{l}\text { R. Oir } \\
\text { Pont }\end{array}$ \\
\hline $\mathrm{D}$ & 667 & 5.60 & 1.07 & 0.30 & 5.60 & 3 & 0.75 & $\begin{array}{l}\text { Levesque } \\
\text { Brook }\end{array}$ \\
\hline $\mathrm{E}$ & 754 & 4.37 & 0.82 & 0.22 & 4.37 & 2 & 1.24 & R. Oir \\
\hline
\end{tabular}

(1) Abbreviation of variables used in figure 5.

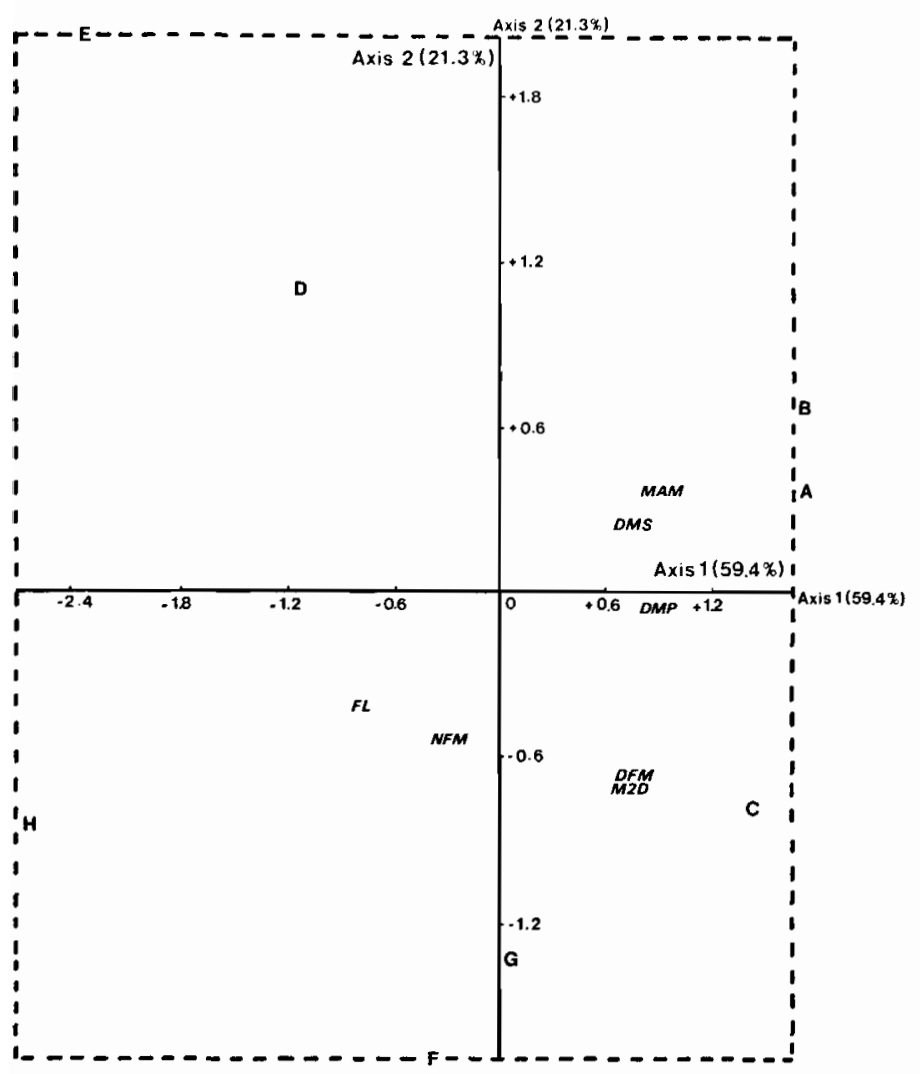

Figure 5. - Localization of variables and individuals within the plan defined with the factorial axes ( 1 and 2). The letters correspond to the eight tracked fish. The variables are in italics: $F L$ : fork length; $M 2 D$ : movement during the first two days; $D M P$ : daily movement during pre-spawning period; DMS: daily movement during spawning period: $D F M$ : distance of the furthest upstream position of migration; NFM: number of days to reach this position; MAM: maximum amplitude of movement. between the size of fish and the maximum amplitude of movement $(r=-0.79, p<0.02)$. Furthermore this last parameter was correlated with the daily movement during pre-spawning period $(r=0.85, p<0.01)$ (fig. 5).

Spawning began in the lower and middle part of the basin on 20 December following an increase of water temperature from 7.5 to $10.5^{\circ} \mathrm{C}$ and a slight increase of water level (29 to $34 \mathrm{~cm}$ ) (fig. 3). The spawning period lasted six days in the River Oir and two days in Pont Levesque Brook (fig. 4). During this phase, three of the salmon $(F, G, H)$ and the largest grilse (D) remained in the same single spawning area. Only three fish (D, G, H) werc observed beside a female. The other grilse moved sequentially to three different spawning areas while the salmon $\mathrm{E}$ moved slowly downstream from a first spawning arca to two others (fig. 4). Over the spawning period, the daily movement of males decreased compared with the pre-spawning period (table 3). It was correlated positively with the daily movement during pre-spawning period $(r=0.73, p<0.05)$ and the maximum amplitude of movement $(r=0.83, p<0.02)$ and negatively with the size of fish $(r=0.71, p<0.05)$ (fig. 5).

Five males $(C, D, E, F, H)$ were found dead at the end of the spawning period (25 and 26 December). The three others stayed on spawning grounds after spawning and were found dead between 28 December 1989 and 1st January 1990 (fig. 4).

\section{DISCUSSION}

The migratory behaviour of the study fish before reaching the trap is not known. In particular, it is not known whether these fish were already present in 
the lower part of the River Oir or whether they ascended this stream from the River Sclune when the conditions of migration became favourable. However, in 1989 the final phase of the migration was greatly delayed compared with the year 1988 because of a prolonged period of low flow and water temperature until mid-December, a period when salmon are usually spawning. Then this migration occurred when the temperature increased from $2.5108^{\circ} \mathrm{C}$ and when the water level rose very slightly. So this shows the possible influence of water temperature on salmon migration at such a period even if, after a prolonged period of low flow, movement may take place at flow that under circumstances would not have provoked movement (Hellawell, 1976). Furthermore, our observations show that high flows do not always secm to be the single necessary factor to permit entry and ascent in the spawning tributary, as reported by Hawkins (1989), Webb (1989) and Webb and Hawkins (1989).

The migratory behaviour of the eight males tracked in this study was characterized by three features.

1. A rapid upstream movement no related to size and lasting two days after the release. This can be explained by the very late timing of the spawning migration in 1989. That year, about $60 \%$ of females trapped and released above the trapping site were ripe and seven of them $(11.1 \%)$ had begun to spawn below the trap. Thus in 1989, most of the adult salmon were already in spawning condition, inducing possibly greater migratory activity in order to reach the spawning grounds. Furthermore, the presence of ripe females above the trap before the day of release could be a stimulating factor (chemical signals) for upstream movement of males above the trap, independently of their size (Thioulouse, 1971; Newcombe and Hartman, 1973; Fontenclle, 1975; Webb and Hawkins, 1989) and water temperature (between 8 and $9^{\circ} \mathrm{C}$ ).

Moreover the observalion of this rapid upstream movement allowed the supposition that the effects of handling on the migratory behaviour may be negligible as reported by Solomon and Storeston-West (1983). However, in a similar study carried out on two Norvegian rivers, Heggberget et al. (1988) considered that these negative effects were most pronounced during the first 5 days after release and that they could modify migratory behaviour during this period. Nevertheless, no rejection of radio transmilter or downstream migration after release (considered to be a response to stress by Baril and Gueneau (1986) was observed in our study.

2. After the first two days, daily movement and maximum amplitude of this one was related to the size of fish. Indeed, our results show the larger the male is, the lower its moving activity, while Webbs and Hawkins (1989) observed similar movements in grilse and multi sea-winter salmon. Furthermore, the daily movement decreased over the spawning period in relation to the size of male.
In our study, after an initial rapid upstream movement, three of the large males stayed in the same area. Of the multi sea-winter fish, only fish $\mathrm{E}$ moved downstream after the beginning of spawning. This difference might be related to the fact that, at this time, male $\mathrm{E}$ was infected by the common aquatic fungus, Saprolegnia sp. and was becoming physically incapacitated. The other large males, which were not infected, showed a migratory behaviour similar to that of females in 1988 (Baglinière et al., 1990) in the sense that they did not move between spawning arcas once spawning had started. In contrast, smaller grilse did not stay on the same spawning site throughout the spawning period by moved among different sites over distances of up to $4 \mathrm{~km}$. The amplitude of the movement observed in male grilse is similar to that recorded for all the males by Webbs and Hawkins (1989) in the Girnock Burn. The streams studied were very comparable. The behaviour of the largest grilse, $\mathrm{D}$, however, was very similar to that of the sea-winter fish as it stayed on the same spawning site in the Pont Levesque Brook.

The differences in behaviour observed between the larger and smaller males may be explained by intraspecific competition for the remales (Jones, 1959; Thioulouse, 1971; Fontenelle, 1975; Beall and Marty, 1983). In a spawning group, the establishment of a system of dominance-subordinance is a characteristic in salmonid males (Chebanov et al., 1983). The rank within the social hierarchy is related to the size of fish, the largest male being often the dominant fish (Jones, 1959; Hartman, 1969; Thioulouse, 1971; Kimura, 1972; Fontenelle, 1975; Keenleyside and Dupuis, 1988). Furthermore, this competition between males could be intensified in River Oir as the sex-ratio was unbalanced in favour of males (table 1).

The salmon males $(F, G, H)$ were almost certainly dominant fish not only because of their size but also because very few other large males had been released above the trap (table 1). The grilse male D was also a dominant fish as it was the largest male of the group of fish present in Pont Levesque Brook. In contrast, the male grilse, A, B, C, were probably subordinate fish as they were amongst the smallest $\left(\mathrm{L}_{\mathrm{F}}=626 \mathrm{~mm}\right)$ of the male grilse recorded in the run (table 1). It is therefore possible that these fish moved away from the main spawning area (49 redds counted on a $1 \mathrm{~km}$ length) located in the River in 1989 at $8 \mathrm{~km}$ on an average from the trap as a result of aggression by the large males.

In our study, we have no direct evidence for successful spawning of tagged males. However, from their study, Webbs and Hawkins (1989) suggested that a long duration of residence in a short length of river may be indicative of successful spawning and inversely extensive movements in males might be an indicator of a lack of spawning. So in our study, we could presume the salmon $(F, G, H)$ and the grilse $D$ would probably have spawned and the other fishes 
would have certainly very little spawning success. Nevertheless, a decrease in daily movement of grilse males $\mathbf{A}$ and $\mathbf{B}$ over the spawning period suggested that these fish could have spawned in the downstream part of the river.

3. A small amount of movement after the spawning period. These fish hardly moved from the vicinity of the spawning grounds (Jones, 1959; Thioulouse, 1971; Fontenelle, 1975; Webb and Hawkins, 989).

At the end of the study period, all the males were found dead. This fact agreed with the very low percentage of male kelts recaptured usually in the downstream trap: $1.2 \%$ for the period 1984-1989 in the River Oir, unpubl. data.

\section{Acknowledgements}

We thank F. Marchand, R. Delanoe for technical assistance, and F. Travade (Électricité de France) for the gift of radiotracking apparatus.

\section{REFERENCES}

Baglinière J. L., G. Maisse, A. Nihouarn, 1990. Migratory and reproductive hehaviour of female aduit atlantic salmon, Salmo sular L., in a spawning stream. J. Fïsh Biol., 36, 511-520.

Baglinière J. L., G. Maisse, A. Nihouarn, J. P. Porcher, P. M. Le Gloannec, 1988. Comparaison de deux méthodes d'estimation de la production naturelle de smolts de saumon atlantique (Salmo salar L.). Bull. Fr. Pêche Piscic., 308, 24-34.

Baril D., P. Guencau, 1986. Radio-pistage de saumons adultes (Salmo Salar) en Loire. Bull. Fr. Pêche Piscić., 302, 86-105.

Bcall E., C. Marty, 1983. Reproduction du Saumon atlantique Salmo salar L. en milicu semi-naturel contrôlé. Bull. Fr. Pêche Piscic., 289, 77-93.

Chebanov N. A., N. V. Varnavskaya, V. S. Varnevskii, 1983. Assessment of successful participation in spawning of male sockeye salmon Oncorhynchus nerka (Walbaum) (Salmonidae) of different hierarchical status with the help of genetic biochemical markers. Vopr. Ikhtiologii, 23, 774-778.

Fontenelle G., 1975. Recherches sur le saumon atlantique (Salmo salar L., 1776) en Bretagnc. 1. Caractéristiques des saumons atlantiques adultes des principales rivières de Bretagne et de Basse-Normandie. 2. Premiers éléments d'une dynamique de population de saumon atlantique dans un affluent du Blavet, Morbihan : aspects ćcoéthologiques. Thèse du $3^{\mathrm{e}}$ cycle, Univ. Rennes, $161 \mathrm{p}$.

Hartman G. F., 1969. Reproductive biology of the Gerrard stock rainbow Trout. Symposium on Salmon and Trout in streams, H. R. Mac Millan Lectures in Fisherics, University of British Columbia, p. 53-67.

Hawkins A. D., 1989. Factors affecting the timing of entry and upstream movement of Atlantic salmon in the Aberdecnshire Dee. In: Proceedings of the salmonid migration Symposium, Trondheim, June 1987, E. L. Brannon,
B. Jonsson (eds.), School of Fisheries, University of Washington, Seattle, $n^{\circ}$ 793, 101-105.

Hawkins A. D., G. W. Smith, 1986. Radio-tracking observations on Atlantic salmon ascending the Aberdeenshire Dee. Scott. Fish. Res. Rep., n³6, 24 p.

Heggherget T. G., L. P. Hansen, T. F. Nacsje, 1988. Within-river migration of Atlantic salmon (Salmo salar). Can. J. Fish. Aquat. Sci., 45, 1691-1698.

Hellawell J. M., 1976. River management and the migratory bchaviour of salmonids. Fish. Manage., 7, 57-69.

Jones J. W., 1959. The salmon. London, Collins, $192 \mathrm{p}$.

Jones J. W., G. M. King, 1949. Experimental observations on the spawning of Atlantic salmon (Salmo salar). Proc. Zool., 119, 33-48.

Keenlcyside M. H., M. C. Hélène Dupuis, 1988. Courtship and spawning competition in Pin Salmon (Oncorhynchus gorbuscha). Can. J. Zool., 66, 262-265.

Kimura S., 1972. On the spawning behavior of the fluvial dwarf form of Masu Salmon, Oncorhynchus masou J. Ichthyol., 19, 111-119.

Laughton R., 1989. The movements of Adult salmon within the River Spey. Scott. Fish. Res. Rep., n 41, 19 p.

Newcombe G., G. F. Hartman, 1973. Some chemical signals in the spawning bchaviour of rainbow Trout (Salmo gairdneri). J. Fish. Res. Board Can., 30, 995-997.

Power J. H., J. D. McCleave, 1980. Riverine movements of hatchery rearcd Atlantic salmon (Salmo salar) upon return as adults. Env. Biol. Fish., 5, 3-13.

Solomon D. J., T. J. Storeton-West, 1983. Radiotracking of migratory salmonids in rivers: development of an effective system. Fish. Res. Techn. Rep., MAFF Direct. Fish. Res., Lowestoft, n 75,11 p.

Thioulouse G., 1971. Le comportement du saumon de l'Allier. Essai d'Éthologic. Clermont-Ferrand: Scient. Plein Air, 49 p.

Webb J., 1989. The movements of adult Atlantic salmon in the river Tay. Scott. Fish. Res. Rep., n $n^{\circ} 44,32$ p.

Webb J., A. D. Hawkins, 1989. The movements and spawning behaviour of adult salmon in the Girnock Burn, a tributary of the Aberdecnshire Dee, 1986. Scott. Fish. Res. Rep., nं40, 42 p. 